\title{
Endovascular treatment of the carotid-cavernous vascular lesions
}

Tratamento endovascular das lesões vasculares carotidocavernosas

\author{
Guilherme Brasileiro de Aguiar
}

Resumo da Dissertação de Mestrado “Tratamento endovascular das lesões vasculares carotidocavernosas” apresentada ao Curso de Pós-Graduação em Pesquisa em Cirurgia da Faculdade de Ciências Médicas da Santa Casa de São Paulo. Área de Concentração: Reparação Tecidual. São Paulo SP, 2013.

Orientador: Prof. Dr. José Carlos Esteves Veiga

Coorientador: Prof. Dr. Mario Luiz Marques Conti

Correspondence: Guilherme Brasileiro de Aguiar; Faculdade de Ciências Médicas da Santa Casa de São Paulo; Rua Dr Cesário Motta Jr, 112; 01221-020 São Paulo SP, Brasil; E-mail: guilhermebraguiar@yahoo.com.br

Received 9 April 2014; Accepted 2 May 2014.

\begin{abstract}
Introduction: The treatment of lesions which compromise the cavernous sinus has always constituted a challenge. The endovascular treatment of these lesions has presented diverse alterations over the last years. This study aims to evaluate the endovascular treatment of vascular lesions in the internal carotid artery (ICA), cavernous segment, performed at our service. Method: This is a descriptive study, retrospective and prospective. Patients with aneurysm in the cavernous ICA or direct carotid-cavernous fistula (dCCF) submitted to endovascular treatment were evaluated. Results: Included were 26 patients with intracavernous aneurysms and 10 with dCCF. All aneurysms were treated with ICA occlusion. The dCCF were treated with occlusion of the ICA in seven cases and with selective fistula occlusion in the remaining three. There was an improvement in pain and ocular proptosis in all patients with dCCF. In the patients with intracavernous aneurysms, the incidence of retroorbitary pain went from $84.6 \%$ to a mere $30.8 \%$, following the treatment. Following endovascular treatment, there was an important improvement in the dysfunction of cranial nerves, compromised in both patient groups, mainly in the oculomotor nerve. Conclusion: The endovascular treatment provided an improvement in the patients of this study, especially in the criteria pain and oculomotor nerve dysfunction.
\end{abstract}

Keywords: carotid-cavernous fistula, therapy, therapeutic embolization, carotid artery injuries. 